Maliqi A., Ramabaja Q., Ramadani L., Latifi B. The impact of some morphological characteristics on running 200 meters. Journal of Education, Health and Sport. 2021;11(6):52-59. eISSN 2391-8306. DOI http://dx.doi.org/10.12775/JEHS.2021.11.06.007 https://apcz.umk.pl/czasopisma/index.php/JEHS/article/view/JEHS.2021.11.06.007 https://zenodo.org/record/4940040

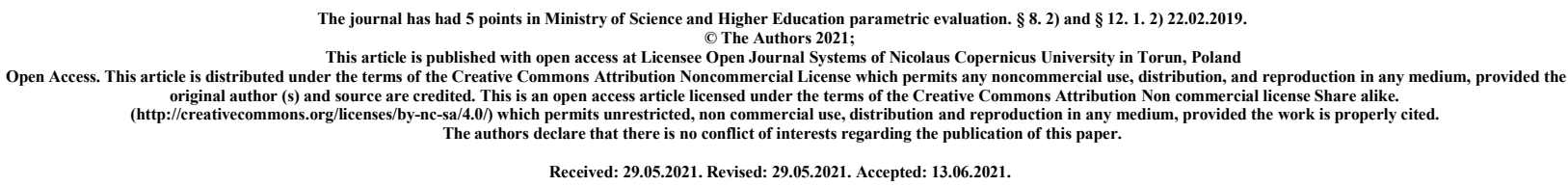

\title{
The impact of some morphological characteristics on running 200 meters
}

\author{
Maliqi, A. ${ }^{1}$, Ramabaja, Q. ${ }^{1}$, Ramadani, L. ${ }^{2}$, Latifi, B. ${ }^{1}$ \\ ${ }^{1}$ AAB College, Physical Culture and Sport, Prishtina, Kosovo \\ ${ }^{2}$ Faculty of Physical Education, Sports and Health, Skopje, Northern Macedonia
}

\begin{abstract}
The knowledge of morphological development and their impact on motor skills in short-distance athletes should be one of the main concerns of athletics coaches, because any scientific research in the field of physical culture and sports is about proving the development and evaluation of anthropological characteristics which are responsible for achieving success in athletics. This paper explores the impact of some anthropometric features on running 200 meters. The aim is to establish the link between the anthropometric and specific characteristics of running 200 meters, as a predictive system of running at 200 meters as a criterion system. The research was conducted by 60 male students aged $17 \pm 6$ months, in the gymnasium "Zenel Hajdini" Gjilan. The measurements were executed during September in the hall of the gymnasium, while the 200, meter runs in the stadium "City stadium "Gjilan. The only condition that was used during the determination of the sample was: that the students are involved in regular physical education classes (and on the day of the measurement be healthy, without the flu, cold or other symptoms). The variables which are applied in this research have been 8 anthropometric variables and 1 motor-specific variables. The results obtained after their processing indicate that the impact of anthropometric variables is higher in running at 200 meters. Short distance running and long-distance running reduces the impact of anthropometric parameters whereas the influence of metabolic factors of energy production is increased. These results were also confirmed using regression analysis, so that groups of predictors of anthropometric characteristics, specific motor skills that statistically significantly influenced each variable of individual criteria. The world records below the 19.20-second limit, in the $200 \mathrm{~m}$, near the 19meter limit, show not only the high level of sports, but also the strong impact on the growth, especially of strength indicators, speed-strength, explosive force, as main and applied motor skills in sports and athlete's everyday life.
\end{abstract}


Key words: anthropometry, criterion variables $200 \mathrm{~m}$., regression, student.

\section{INTRODUCTION}

Athletics is one of basic sports and an essential branch of the Physical Education, as well as running, notably as racing discipline, which dates back from old games, respectively the first Olympic games of 776 B.C., where running in one period (129 meters), was the only run racing discipline [1]. It is known as the Queen of sports because there are several branches and motile disciplines within it. Running, notably in short paths, is part of some studies and researches because they have a specific variety, notably running in 200 meters as typical sprint running, which is the studying object in this research. Athletics affects the strengthening of health, during active participation with walking, walking-running and running, in different cross country of individual and massive character, which develop regularly. Running is the most universal mean of comprehensive preparation of the athlete, but it also occupies a very important place in the training of other types of sports. During running, the body appears more demands on the work of the muscular system and cardiovascular and respiratory activity. It is an important mean for maintaining and strengthening health. Athletic running, as a set of physical movements of a cyclic character, realizes displacement in space and time through steps with the lower limbs (legs) at a higher speed than in race walking. Running speeds, as well as long jumps and triple jumps, are natural forms of movement performance in general, and athletics in particular. These types are one of the basic means of comprehensive preparation: physical, functional and psychological $[2,3]$.This is the main reason why they are constantly evaluated, especially in the context of purposeful exercise for sports achievements. Climatic conditions play a role in running results. The wind, depending on which direction it blows, can affect the growth or deceleration of the athlete's speed. Although it applies to all competitors in a given place and moment, the problem is that the results of a wind-blown place may be different from the results of another event in the same discipline, so in running 200 meters. [4,5] Atmospheric pressure or air pressure may be considered, but it has no effect because running is too short and the amount of oxygen for this distance is mostly concentrated in the muscles of the runners. An athlete may not have building muscles, but he is taller and has the largest step. In this context, statistical tests and interpretation of results in separate sub-headings have been performed.

\section{PURPOSE OF THE RESEARCH}

Like any research of a transversal character that aims to prove the relationships, impact, dependence between different anthropological characteristics, skills and conditions, even this research is based on proving the influence of one anthropological field with the other in order to increase the information in favor of identifying the factors that are of particular importance in increasing the motor skills of anaerobic character speed.

The knowledge of morphological development and their impact on motor skills of athletes in short tracks should be one of the main concerns of athletics coaches, because any scientific 
research in the field of physical culture and sport is about proving the development and evaluation of anthropological characteristics which are responsible for achieving success in athletics.

The purpose of this paper is to confirm the impact of some anthropometric characteristics on the speed of execution of running on short tracks, specifically in running 200 meters for students aged $17 \pm 6$ months.

\section{SAMPLE OF VARIABLES Anthropometric variables}

The following morphological parameters have been applied for the identification of morphological variables: Body Height (BH), Leg Length (LL), Body Weight (BW), Chest Circumference (ChC), Elbow Diameter (ED), Knee Diameter (KD), Subcutaneous Adipose Tissue of the arm (SATAr) and Subcutaneous Adipose Tissue of the abdomen (SATAb).

\section{Specific-motor variables}

The following parameters have been applied for the identification of specific motor skills:

Running 200 meters from low start (R200M)

\section{INTERPRETATION OF RESULTS AND DISCUSSION DESCRIPTIVE ANALYSIS OF ANTHROPOMETRIC AND MOTOR SPECIFIC VARIABLES}

In Table 1, descriptive analysis of anthropometric and motor specific variables is presented to the students of aged $17 \pm 6$ months.

The sample included a group of 60 male students, where the arithmetic mean values, minimum score, maximum score, standard deviation, distribution or asymmetry parameters (Skewness - tilt, asymmetry) and the degree of extension of the curvature peak of the distribution of results (Kurtosis - convexity).

Table 1. Basic statistical parameters of anthropometric and motor specific variables in students of aged $17 \pm 6$ months

\begin{tabular}{|l|r|r|r|r|r|r|r|}
\hline & $\mathrm{N}$ & \multicolumn{1}{|c|}{ Minimum } & Maximum & \multicolumn{1}{c|}{ Mean } & Std. Deviation & Skewness & Kurtosis \\
\hline BH & 60 & 156.70 & 184.60 & 172.6550 & 5.61772 & -.151 & .360 \\
\hline LL & 60 & 85.80 & 105.40 & 96.7195 & 4.73850 & -.283 & -.617 \\
\hline BW & 60 & 49.40 & 93.50 & 64.0083 & 7.96312 & 1.073 & 2.549 \\
\hline ChC & 60 & 76.90 & 100.40 & 85.6150 & 6.03748 & .824 & -.276 \\
\hline ED & 60 & 6.00 & 9.90 & 7.4550 & .74480 & 1.062 & 1.651 \\
\hline KD & 60 & 8.70 & 12.60 & 10.0683 & .70579 & .824 & 2.224 \\
\hline SATAr & 60 & 3.80 & 19.60 & 7.2183 & 3.06448 & 1.842 & 4.167 \\
\hline SATAb & 60 & 4.80 & 24.20 & 10.0550 & 4.78300 & 1.463 & 1.588 \\
\hline R200M & 60 & 25.08 & 39.77 & 29.7018 & 3.13092 & 1.214 & 1.665 \\
\hline
\end{tabular}

The arithmetic mean of the anthropometric variable, Body height $(\mathrm{BH})$ is $172.65 \mathrm{~cm}$. Minimum results $(156.70 \mathrm{~cm})$ and the maximum $(184.60 \mathrm{~cm})$ of the variable. Body height $(\mathrm{BH})$ indicates a 
marked difference between students of this age in this anthropometric parameter. Although the results indicate that there is a marked difference between the maximum and minimum result, it can be seen that the flexibility and convexity of the obtained distribution (Skewness and Kurtosis) do not indicate a pronounced asymmetry...

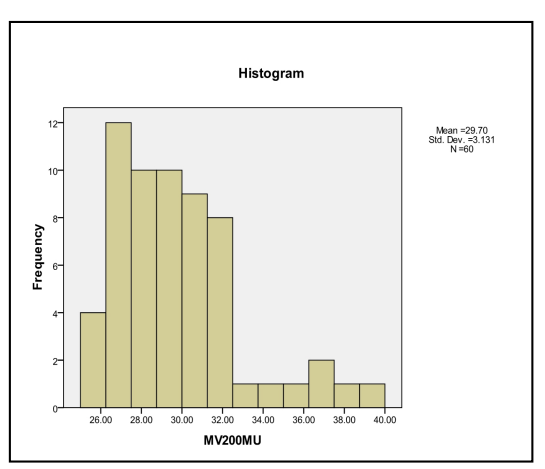

Histogram 1, of the specific motor variable, running 200 meters from low start (MV200MU) to students aged $17 \pm 6$ months. The arithmetic mean of the specific motor variable, Running 200 meters from low start (R200M) is 29.70 sec. Minimum result $(25.08 \mathrm{sec})$ and the maximum $(39.77 \mathrm{sec})$ of the variable Running 200 meters from low start indicates a significant difference between students of this age in this specific motor parameter. Although the results show that there is a marked difference between the maximum and the minimum result, it can be seen that the flexibility and convexity of the obtained distribution (Skewness and Kurtosis) do not indicate a pronounced asymmetry.

\section{Regressive analysis of anthropometrics and specific motor parameters}

Through regressive analysis in students, the value of the correlation between the group of independent predictor variables (anthropometric variables) and the dependent criterion variable Running at 200 meters from low start (R200M) has been proven. 
Table 2. Regressive analysis - correlation and effect of anthropometric parameters (as predictor variables) on the criterion variable - Running 200 meters from low start

\begin{tabular}{|l|r|r|r|rr|}
\hline Model & R & R Square & Adjusted R Square & Std. Error of the Estimate \\
\hline 1 & $.565^{\mathrm{a}}$ & .320 & .213 & 2.77782 \\
\hline \multicolumn{7}{|r}{ a. Predictors: (Constant), BH,LL,BW,ChC,ED,KD,SATAr, SATAb } \\
\hline
\end{tabular}

\begin{tabular}{|l|l|r|r|r|r|r|}
\hline \multicolumn{1}{|l|}{ Model } & Sum of Squares & df & Mean Square & \multicolumn{1}{c|}{ F } & Sig. \\
\hline 1 & Regression & 184.829 & 8 & 23.104 & 2.994 & $.008^{\mathrm{a}}$ \\
\cline { 2 - 7 } & Residual & 393.529 & 51 & 7.716 & & \\
\cline { 2 - 6 } & Total & 578.358 & 59 & & & \\
\hline
\end{tabular}

\begin{tabular}{|c|c|c|c|c|c|c|}
\hline \multirow{2}{*}{\multicolumn{2}{|c|}{ Model }} & \multicolumn{2}{|c|}{ Unstandardized Coefficients } & \multirow{2}{*}{$\begin{array}{c}\text { Standardized Coefficients } \\
\text { Beta }\end{array}$} & \multirow[b]{2}{*}{$\mathrm{t}$} & \multirow[b]{2}{*}{ Sig. } \\
\hline & & $\mathrm{B}$ & Std. Error & & & \\
\hline \multirow{9}{*}{1} & (Constant) & 67.084 & 15.920 & & 4.214 & .000 \\
\hline & $\mathrm{BH}$ & -.363 & .158 & -.652 & -2.305 & .025 \\
\hline & LL & .107 & .157 & .162 & .681 & .499 \\
\hline & BW & .051 & .101 & .131 & .512 & .611 \\
\hline & $\mathrm{ChC}$ & .106 & .102 & .204 & 1.034 & .306 \\
\hline & ED & -.463 & .586 & -.110 & -.790 & .433 \\
\hline & KD & .661 & .760 & .149 & .870 & .389 \\
\hline & SATAr & .453 & .222 & .443 & 2.042 & .046 \\
\hline & SATAb & -.381 & .164 & -.582 & -2.321 & .024 \\
\hline
\end{tabular}

The correlation of the entire system of independent predictor variables (anthropometric variables) and the criterion dependent variable - 200 meters run from low start (R200M) has been proven by multiple correlations. The multiple correlation coefficient has the value $\mathrm{R}=0.565$ which explains the common variability between the system of predictor variables and the criterion variable about 32\% (R Square $=0.320$ ). Distribution $(F)$ is obtained as the quotient distribution of the two variances, and it is always necessary in these cases to determine the two degrees of freedom. The first degree of freedom is equal to the number of predictor variables $(\mathrm{df}=\mathrm{n})$ in the concrete case whereas $(\mathrm{df}=8)$ the second is performed so that the number of subjects decreased by the number of predictor variables minus $1(\mathrm{df}=\mathrm{N}-\mathrm{n}-1)$ in the concrete case whereas $(\mathrm{df}=$ $60-8-1=51$ ). We can emphasize that the test (F-test) is more valuable if the multiple correlation is greater, in the concrete case of this paper is significant ( $\mathrm{Sig}=0.008$ ), because the value of the F-test is $=2.994$. In this research after a significant multiple correlation has been obtained (R) it is necessary to look for which coefficient in the beta column (Beta) that indicates the effect of each predictor (independent) variable on the dependent or criterion variable, Running 200 meters from the low start (R200M), table 2. The results obtained from regressive analysis indicate that in the dependent variable or Running 200 meters from low start (R200M) 
the anthropometric variable Body height $(\mathrm{BH})$ has an effect, Beta $=-.652$ which is proven by the degree of probability, Sig $=0.025$, then influence from the group of anthropometric predictive variables on the manifestation of the criterion variable: Running 200 meters from the low start (R200M, given the previously defined level of significance of $\mathrm{P}<.05$, thus regression coefficient or higher influence, from other anthropometric predictive variables also have: Subcutaneous Adipose Tissue of the arm (SATAr) with Beta coefficient $=.443$ which is proven by the degree of probability, Sig $=0.046$.and Subcutaneous Adipose Tissue of the abdomen (SATAb) with Beta coefficient $=-.582$ which is proven by the degree of probability, Sig $=0.024$.

Body height, respectively leg length, step length and segmental speed expressed by the speed of foot movement, are important factors that help in the speed of execution of Running at 200 meters from the low start (R200M).

\section{CONCLUSION}

It is known that the sports training system in athletics, respectively short-distance running consists of the training or preparation system, competition system and complementary factor system. The overall system of preparation of athletes is oriented towards the development and maintenance of general skills, qualities and knowledge on which success depends on the conditions of competitions. The athletic training process has many tasks which are solved through physical preparation, technical preparation, tactical preparation, psychological preparation and theoretical preparation. The purpose of this research is also based on these facts, which aims to prove the influence of some anthropometric characteristics on short-distance running. So, the purpose of this paper is presented based on these presented facts about the influence of morphological factors on short-distance running. In this paper (research) the population from which the sample was selected for research on this paper is defined as the population of students (male) of late adolescence.

The sample of this research has included a total of 60 male students aged $17 \pm 6$ months, in the gymnasium "Zenel Hajdini" Gjilan. For both groups of the variable systems, the basic statistical and distribution parameters for each variable were calculated, as well as the asymmetry and normal distribution measures, the correlation ratio, and regression analysis.

The results obtained from the collection of information as well as their processing show that:

Some of the anthropometric characteristics have had pronounced asymmetry indicating that the sample has been heterogeneous in conditions of morphological development. Some of the specific-motor speed skills have had marked asymmetry indicating that the sample has been heterogeneous with different results. Anthropometric characteristics are grouped according to anthropometric factors which means that anthropometric characteristics of length are grouped as longitudinal factors, anthropometric characteristics of weight and perimeter are grouped as a factor of body mass and volume. Anthropometric characteristics of the subcutaneous adipose tissue of the arm and abdomen are grouped as a factor of subcutaneous fat mass. The results obtained from regression analysis indicate that in the dependent variable or kriteria. The results obtained from regressive analysis indicate that in the variable $200 \mathrm{~m}$ running from low start (R200M) it does not affect any anthropometric variables applied. We can conclude that running on short tracks 200 meters, running on middle distances and long distances the effect of anthropometric parameters is decreased and the influence of metabolic factors of energy production is increased. 


\section{REFERENCES}

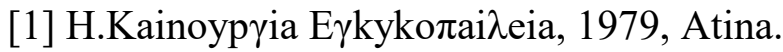

[2] Ramadani L., Heta G., Bekolli L., Rashiti N., Millaku A., "Journal of Education, Health and Sport", "The impact of short run distances to the final results of the decathlon at the 2019 Athletic World Championships", 2019;9(12):101-109.

[3] Rashiti, V., Ramadani L., Rashiti N., "St. Kliment Ohridski University", "The pole of the students educational background at elementary schools and their tesults", Faculty of Education Bitola, Vol. 9, No. 1, God. 2020/2

[4] G, Heta., L, Bekolli., L, Ramadani., Q, Ramabaja., N, Rashiti.,” Difference between midfield and forward football players in active and passive Body Mass Index as well as in the aerobic capacity" Open Access ISSN 2391-8306 formerly ISSN: 1429-9623 / 2300- 665X, 2020

[5] Rashiti, N., Myrtaj, N.,Xhemajli, V. Canon anthropometric relationship between the characteristics and spesific motor abilities in football club in Gjilani. Zbornik: Nauchni trudove Vol. 50, book 8.2. Physical Education and Sport (f. 138-141), 2011. Ruse: University of Ruse,, Angel Kanchev"

[6] Rhea M. R., "Determining the magnitude of treatment effects in strength training research through the use of the effect size," Journal of Strength and Conditioning Research, vol. 18, no. 4, pp. 918-920, 2004. DOI: 10.1519/14403.1

[7] Rashiti, N., Nika, F., Bekolli, L., Heta, G., "Jurnal of physical activity and sports" "Difference Betwen finalists in anthopometric parameters and 100 meters running of top athlete" vol. 2, no. 3, pp. 1-8, 2017.

[8] Rashiti N., Meta A ., "Studime Sportive" , "Funksioni i aparatit vestibular nëveprimtaritë sportive", Vol. 5, No. 2. Pp. 7, 2002 Tiranë.

[9] Rashiti N., Elezi A., Maliqi A., "Nacionalnata sportna akademija“, "Impact of some motor abilities on the manifestation of endurance with highschool students at the age 16 years", "V. Levski" broji 1 -10, 2010, Sofia.

[10] Rashiti N., Nika F., Sylejmani B., "Montenegrin sport academy" "Prediktivna vrjednost baterije motoricnih testova na tercanje kratki i srednjih staze" Vol. 7, No. 3, pp.1-5,2011, Montenegro.

[11] Spurrs, R.W., Murphy, A.J., \&Watsford, M.L. (2003). The effect of plyometric training on distance running performance.Eur J ApplPhysiol, 89(1), pp.1-7.

[12] Kaynak K., Eryılmaz S. K., Aydoğan S., Mihailov D., "The effects of 20-m repeated sprint training on aerobic capacity in college volleyball players," Biomedical Human Kinetics, vol. 9, no. 1, pp. 43-50, 2017. DOI: $10.1515 /$ bhk-2017-0007

[13] Kotzamanidis C., "The effect of sprint training on running performance and vertical jumping in prea-dolescent boys," Journal of Human Movement Studies, vol. 44, no. 3, pp. 225240, 2003.

[14] Mero A., Komi P. V., Gregor R. J., "Biomechanics of sprint running. A review," Sports Medicine, vol. 13, no. 6, pp. 376-392, 1992. DOI: 10.2165/00007256-199213060-00002

[15] Maliqi, A., Myrtaj, N.,Sylejmani, \& B., Xhemajli A.The difference in some anthropometric characteristics, motoric and specific motoric skills between the students and athletes of the age 15.Journal of Pedagogical Almanac, 28(2), 254-260, 2020.

[16] Rashiti, N., Myrtaj, N.,Tahiri, S., Nika, F., Shkodra, M. (2010).Characteristics anthropometric and motor tests for short running on 100 meters (females). Zbornik: Nauchnitrudove Vol. 49, book 8.2. Physical Education and Sport (f. 63-68), 2010. 
[17] Xhemajli,V.,Myrtaj,N.,Xhemajli,A. Povezanost motoričkih i morfoloških karakteristika učenika s uspješnosti u trčanjena 60 metara.Časopis Sport Mont, 34, 35, 36./X, 201-206, 2012.

[18] Maliqi, A., Morina, A., Sylejmani, B., Maliqi, FA. The impact of basic-motor skills in speedy long jump and 60 meters low start. Sportski Logos,15,35-38, 2017.

Correspondence to:

Ramabaja Qëndresa, prof.

AAB COLLEGE

Faculty of Physical Education and Sport, Prishtina, Kosova

E-mail: qendresaramabaja@hotmail.com 